\title{
Dysfunction of the RAR/RXR signaling pathway in the forebrain impairs hippocampal memory and synaptic plasticity
}

\author{
Masanori Nomoto ${ }^{1,2}$, Yohei Takeda ${ }^{1}$, Shusaku Uchida ${ }^{1}$, Koji Mitsuda ${ }^{1}$, Hatsune Enomoto ${ }^{1}$, Kaori Saito ${ }^{1}$, Tesu Choi ${ }^{1}$,
} Ayako M Watabe ${ }^{3,4}$, Shizuka Kobayashi ${ }^{3}$, Shoichi Masushige ${ }^{1}$, Toshiya Manabe ${ }^{3}$ and Satoshi Kida ${ }^{1,2^{*}}$

\begin{abstract}
Background: Retinoid signaling pathways mediated by retinoic acid receptor (RAR)/retinoid $\times$ receptor (RXR)mediated transcription play critical roles in hippocampal synaptic plasticity. Furthermore, recent studies have shown that treatment with retinoic acid alleviates age-related deficits in hippocampal long-term potentiation (LTP) and memory performance and, furthermore, memory deficits in a transgenic mouse model of Alzheimer's disease. However, the roles of the RAR/RXR signaling pathway in learning and memory at the behavioral level have still not been well characterized in the adult brain. We here show essential roles for RAR/RXR in hippocampus-dependent learning and memory. In the current study, we generated transgenic mice in which the expression of dominantnegative RAR (dnRAR) could be induced in the mature brain using a tetracycline-dependent transcription factor and examined the effects of RAR/RXR loss.

Results: The expression of dnRAR in the forebrain down-regulated the expression of RAR $\beta$, a target gene of RAR/ $R X R$, indicating that dnRAR mice exhibit dysfunction of the RAR/RXR signaling pathway. Similar with previous findings, dnRAR mice displayed impaired LTP and AMPA-mediated synaptic transmission in the hippocampus. More importantly, these mutant mice displayed impaired hippocampus-dependent social recognition and spatial memory. However, these deficits of LTP and memory performance were rescued by stronger conditioning stimulation and spaced training, respectively. Finally, we found that pharmacological blockade of RAR $\alpha$ in the hippocampus impairs social recognition memory.

Conclusions: From these observations, we concluded that the RAR/RXR signaling pathway greatly contributes to learning and memory, and LTP in the hippocampus in the adult brain.
\end{abstract}

\section{Background}

Retinoic acids (RAs) are biologically active metabolites of vitamin A, an essential nutrient factor [1-3]. Vitamin A-RA signaling pathways play essential roles in a wide range of biological functions such as reproduction, growth, differentiation, development, vision, and homeostasis of various tissues, including the brain $[2,4]$.

All-trans-RA and 9-cis-isomers of RA bind to their nuclear receptor, i.e., RA receptors (RAR $\alpha, \beta$, and $\gamma$ ) and retinoid $\times$ receptors $(\mathrm{RXR} \alpha, \beta$, and $\gamma)$, which function as ligand-inducible transcription factors [4,5]. RA

\footnotetext{
* Correspondence: kida@nodai.ac.jp

'Department of Bioscience, Faculty of Applied Bioscience, Tokyo University

of Agriculture, Tokyo 156-8502, Japan

Full list of author information is available at the end of the article
}

binding to RAR and RXR, respectively, forms a heterodimer of RAR/RXR or a homodimer of RXR/RXR and regulates the transcription of target genes by binding to retinoic acid responsive elements in their promoter regions, thereby regulating various biological phenomena $[4,6]$.

RAR and RXR, especially RAR $\alpha$ are highly expressed in a wide range of central nervous system tissues including the mature brain $[7,8]$. Moreover, there is growing evidence that vitamin A-RA signaling pathways have an impact on higher brain function; furthermore, an impairment of these signaling pathways is implicated in the etiology of Alzheimer's disease and psychiatric disorders such as schizophrenia [9-15]. Indeed, recent studies using mice have shown that age-related memory deficits are 
associated with the hypo-function of vitamin A-RA signaling pathways and these deficits are restored by treatment with RA or supplementation of vitamin A $[16,17]$.

Importantly, deletion of the RAR $\beta$ or RAR $\beta / R X R \gamma$ genes leads to deficits in hippocampal synaptic plasticity, e.g., long-term potentiation (LTP) and long-term depression (LTD) [18]. Similarly, vitamin A-deficient mice display impaired hippocampal LTP that is rescued by treatment with RA $[19,20]$. These findings strongly suggest that the RAR/RXR signaling pathway plays critical roles in hippocampal LTP and LTD. However, the roles of the RAR/RXR signaling pathway in learning and memory have not been well characterized in the mature brain, especially in the hippocampus. Indeed, previous genetic studies have shown that mice lacking the RAR $\beta$ or $\mathrm{RAR} \beta / \mathrm{RXR} \gamma$ genes displayed deficits in motor coordination that made it difficult to estimate their learning and memory abilities [21]. However, these studies suggested that loss-of-function of the RAR/RXR signaling pathway impairs spatial learning and memory [18]. Additionally, these studies did not exclude the possibility that genetic depletion of the RAR/RXR genes leads to some developmental changes in the brain.

In the current study, we tried to understand the roles of the RAR/RXR signaling pathway in hippocampusdependent learning and memory and in hippocampal synaptic plasticity. To do this, we generated conditional mutant mice in which the expression of a dominantnegative mutant of RAR $\alpha$ could be induced in the forebrain using a tetracycline-dependent transcription factor, and performed electrophysiological experiments and hippocampus-dependent memory tasks using these transgenic mice. Furthermore, we examined the effects of pharmacological inhibition of RAR $\alpha$ in the hippocampus on memory performance.

\section{Results}

RARs, especially RAR $\alpha$, are abundantly expressed in the forebrain, including the hippocampus $[7,8]$. To understand the roles of the RAR/RXR signaling pathway in learning and memory and synaptic plasticity, we examined the effects of impaired RAR/RXR function in the forebrain. To do this, we generated mutant mice in which a dominant-negative mutant of RAR $\alpha$ (dnRAR) was expressed specifically in the forebrain using a tetracycline system [22-25]. This mutant protein, lacking the C-terminus (amino acid (aa) 403-462) of RAR $\alpha$ (aa 1462), forms a heterodimer with RXR, but is unable to induce transcriptional activation [26]. In these mutant mice, a tetracycline-dependent transcriptional activator (tTA) expressed in the forebrain activates the expression of dnRAR specifically in this brain region in the absence of tetracycline, whereas the expression of dnRAR is suppressed when the mice are administrated doxycycline
(Dox), a derivative of tetracycline, in their drinking water (Figure 1A).

\section{Generation of dnRAR mice}

We first generated two lines ( $\mathrm{H} 02$ and H06) of mutant mice that express dnRAR fused with an HA-tag at the Nterminus under the control of a tetracycline-responsive element (TRE)-dependent promoter (TRE-dnRAR mice) [27]. These mutant mice were crossed with transgenic mice that express tTA in the forebrain under the control of the $\alpha$ CaMKII promoter, which displays strong activity in the forebrain including the hippocampus, cortex, and amygdala (CaMKII-tTA mouse) [24], generating 2 lines of CaMKII-tTA/TRE-dnRAR double transgenic mice (dnRAR H02 and H06 mice).

To decrease the effects of dnRAR expression on the development of the forebrain, transgenic mice and wildtype (WT) littermates were treated with Dox until they were 8 weeks old and they were then housed without Dox-treatment to induce the expression of dnRAR (transgene OFF - transgene ON; OFF/ON; Figure 1B). For the control groups, dnRAR H06 mice were treated with Dox throughout their lifetime (transgene OFF; OFFdnRAR mice) and OFF/ON-dnRAR H06 mice were treated again with Dox for 4 weeks following withdrawal of Dox for 4 weeks (transgene OFF-transgene ON-transgene OFF; OFF/ON/OFF-dnRAR mice; Figure 1B).

We next performed expression analysis of dnRAR in the forebrain and hippocampus of dnRAR H02 and H06 mice. Northern blot analysis using a specific probe for the 3'-untranslated region (UTR) of dnRAR mRNA revealed that dnRAR mRNA was expressed in the forebrain and hippocampus of the 2 OFF/ON double transgenic lines (Figure 1C). Importantly, dnRAR H02 mice displayed higher levels of dnRAR mRNA expression than the dnRAR H06 mice. Consistently, Western blotting using an anti-HA antibody showed the expression of dnRAR in the hippocampus of OFF/ON-dnRAR H06 mice (Figure 1D). Importantly, the expression of dnRAR was not detectable in the hippocampus of OFF/ON/OFFdnRAR H06 mice. These observations indicated that the dnRAR mice express dnRAR in the forebrain, including the hippocampus, in a Dox-dependent manner.

We finally examined the effects of dnRAR expression on RAR/RXR-dependent gene expression in the forebrain. To do this, we analyzed the expression levels of RAR $\beta$, a target gene of RAR/RXR $[1,28]$, in the forebrain and hippocampus using Northern blotting and quantitative RT-PCR (qRT-PCR) (Figure 1E, F, respectively). One-way analysis of variance (ANOVA) of the Northern blotting results revealed a significant effect of genotype on RAR $\beta$ expression $\left(\mathrm{F}_{(2,21)}=5.953, \mathrm{p}<0.05\right.$; Figure $\left.1 \mathrm{E}\right)$. The post hoc Newman-Keuls test revealed that the expression levels of RAR $\beta$ mRNA in the forebrain of OFF/ON-dnRAR H02 


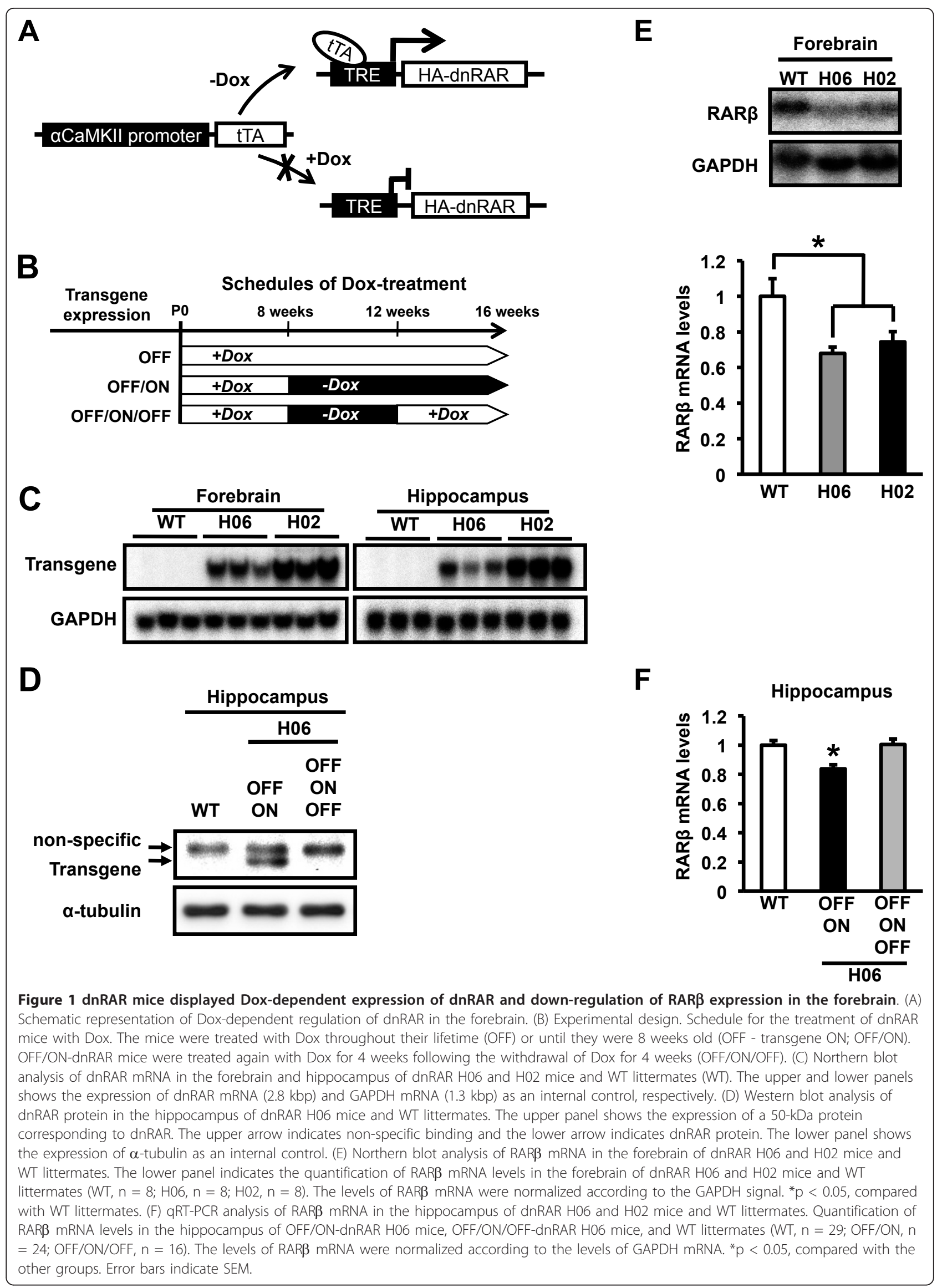


and H06 mice were significantly lower than in WT mice $(\mathrm{p}<0.05)$. Additionally, dnRAR-H06 mice displayed slightly lower expression levels of RAR $\beta$ mRNA than dnRAR-H02 mice, although this difference was not statistically significant. Similarly, qRT-PCR showed that OFF/ ON-dnRAR H06 mice displayed significantly lower expression levels of RAR $\beta$ mRNA in the hippocampus than WT mice ( $\mathrm{p}<0.05$; Figure 1F). Importantly, this decreased expression of RAR $\beta$ mRNA in the hippocampus was rescued when these OFF/ON mice were treated again with Dox for 4 weeks (OFF/ON/OFF-dnRAR mice; OFF/ ON/OFF vs. OFF/ON, $\mathrm{p}<0.05$; OFF/ON/OFF vs. WT, $p>0.05$ ), indicating that the down-regulation of RAR $\beta$ mRNA is dependent on the expression of dnRAR. Collectively, these observations indicated that the expression of dnRAR decreases RAR $\beta$ mRNA levels in the forebrain, including the hippocampus, suggesting that dnRAR expression leads to dysfunction of the RAR/RXR signaling pathway in these brain regions. Our results indicate that the expression levels of dnRAR in the OFF/ON-dnRAR H06 mice are sufficient to downregulate RAR/RXR-target gene expression; therefore, the subsequent electrophysiological and behavioral analyses were performed using the dnRAR-H06 transgenic line.

\section{Basal synaptic transmission and LTP in the hippocampus of dnRAR mice}

Previous studies have shown that genetic deletion of one or two RAR/RXR subtypes impaired LTP in the CA1 region of the hippocampus [18]. To examine the effects of the impaired RAR/RXR signaling pathway on synaptic plasticity, we recorded extracellular field potentials in the CA1 region of hippocampal slices from OFF/ON-dnRAR H06 mice and WT littermates.

We investigated basal synaptic transmission in dnRAR H06 mice. We first analyzed the input-output relationships of AMPA receptor-mediated excitatory postsynaptic potentials (EPSPs) evoked by various stimulus intensities (Figure 2A). We applied a low concentration of CNQX $(1 \mu \mathrm{M})$ to partially block the AMPA receptors because the fiber volleys were usually much smaller than the EPSPs $[29,30]$. dnRAR H06 mice showed significantly small AMPA synaptic responses at each presynaptic fiber volley amplitude (PSFV) compared with WT mice ( $\mathrm{p}<$ 0.05 at each PSFV). These results suggest that AMPA receptor-mediated synaptic responses were decreased in dnRAR H06 mice.

We next analyzed paired-pulse facilitation (PPF), a presynaptic form of short-term synaptic plasticity, in dnRAR H06 mice (Figure 2B). PPF was induced by a pair of afferent fiber stimulations at short intervals (50, 100, 200, or $300 \mathrm{~ms}$ ). dnRAR H06 mice showed comparable PPF at each inter-pulse interval compared with WT mice, suggesting that the probability of release of the neurotransmitter glutamate from the presynaptic terminal is normal in dnRAR H06 mice (each interval, p > 0.05). We also analyzed post-tetanic potentiation (PTP), which is a presynaptic phenomenon (Figure 2C) [31]. PTP was induced by conditioning stimulation $(100 \mathrm{~Hz}$, $1 \mathrm{~s})$ in the presence of D-APV $(50 \mu \mathrm{M})$, an NMDA receptor antagonist. The magnitude of PTP following stimulation was comparable between dnRAR and WT mice, suggesting that short-term plasticity induced by conditioning stimulation was normal in dnRAR mice ( $p>0.05$ at each time point).

Next, we analyzed LTP in dnRAR H06 mice. LTP was induced using a single high-frequency stimulation (one $100 \mathrm{~Hz}, 1 \mathrm{~s}$ train; Figure 2D and 2E). It is important to note that the stimulus strength was adjusted to obtain similar initial EPSP slope values $(0.10-0.15 \mathrm{mV} / \mathrm{ms})$ in each experiment because dnRAR H06 mice displayed impaired AMPA receptor-mediated input-output relationships compared with WT mice (Figure 2A). WT mice displayed significant synaptic potentiation following highfrequency stimulation compared with their baseline responses ( $\mathrm{p}<0.05$; Figure $2 \mathrm{D})$, indicating that single conditioning stimulation was sufficient to induce LTP in the hippocampal slices from WT mice. Conversely, dnRAR H06 mice also displayed significant LTP compared with their baseline responses $(p<0.05)$. However, the magnitude of LTP in these mutant mice was significantly lower at 51-60, 111-120, and 171-180 min following the induction of LTP compared with WT littermates $(\mathrm{p}<0.05$; Figure 2E), although the magnitude was comparable at 2130 min between dnRAR H06 and WT mice ( $>$ > 0.05), suggesting that dnRAR H06 mice failed to maintain LTP even though LTP was induced normally. These observations indicated that dnRAR H06 mice displayed impaired LTP in the CA1 region of the hippocampus.

We examined whether stronger conditioning stimulation rescues the impaired LTP observed in the dnRAR H06 mice. To do this, LTP was induced by four high-frequency stimulations (four $100 \mathrm{~Hz}, 1 \mathrm{~s}$ trains at $5 \mathrm{~min}$ intervals; Figure $2 \mathrm{~F}$ and $2 \mathrm{G}$ ). WT and dnRAR H06 mice displayed significant LTP compared with their baseline responses $(\mathrm{p}<0.05)$. In contrast to the results from single conditioning stimulation, dnRAR H06 mice displayed a comparable magnitude of LTP at each time point compared with WT mice. These observations suggest that strong conditioning stimulation rescued the impaired LTP observed in dnRAR H06 mice. However, we could not exclude the possibility that strong conditioning stimulation led to saturated levels of LTP, thereby masking differences in the magnitude of LTP between WT and dnRAR H06 mice.

We finally examined short-term potentiation (STP; Figure $2 \mathrm{H}$ ). STP was induced by using shorter conditioning stimulation (100 Hz for $100 \mathrm{~ms}$ ) than that used to induce 


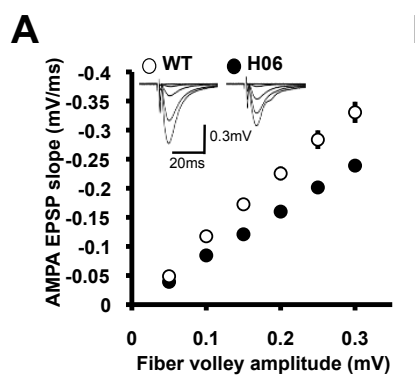

B

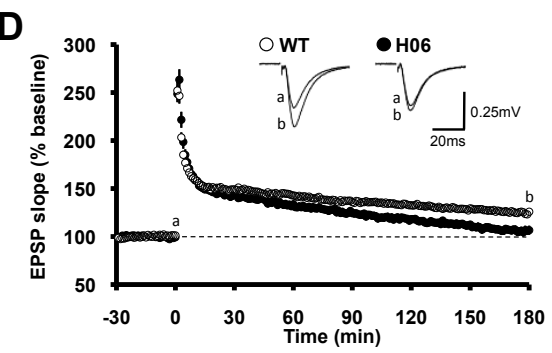

$\mathbf{F}$
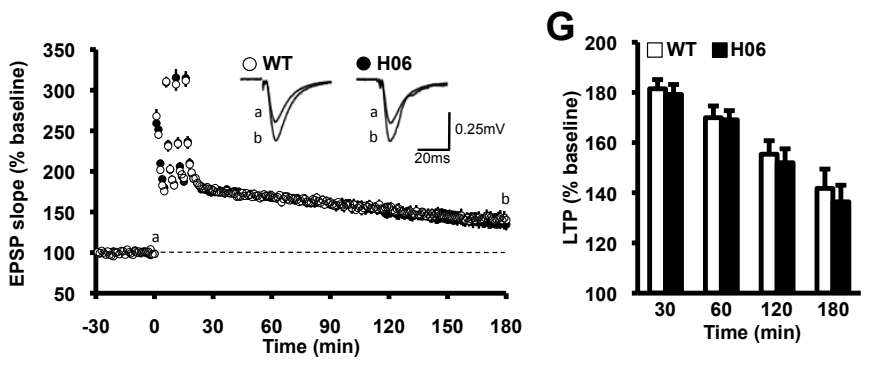

H

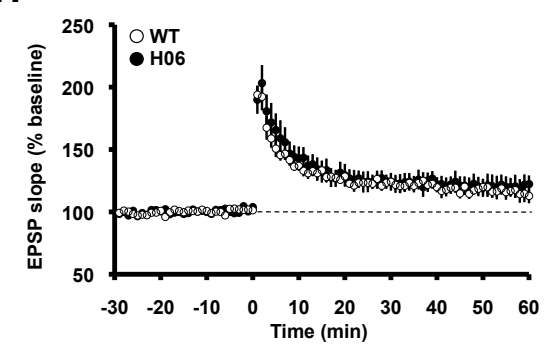

Figure 2 Basal synaptic transmission and LTP in the hippocampus of dnRAR mice. (A) The input-output relationships of AMPA receptormediated EPSP in WT $(n=9)$ and dnRAR H06 $(n=8)$ mice. The sample traces in the inset represent the responses evoked with the five different stimulus intensities and the stimulus artifacts were truncated. The data were first sorted by the amplitude range of the fiber volleys, and then the EPSP slopes were averaged within each range. (B) PPF induced by stimulating afferent fibers twice at intervals of 50, 100, 200, and 300 ms in WT $(n=9)$ and dnRAR H06 $(n=8)$ mice. (C) PTP induced by high-frequency stimulation (one $100 \mathrm{~Hz}, 1 \mathrm{~s}$ train) in the presence of D-APV $(50 \mu \mathrm{M})$ in WT (139.2 $\pm 3.5 \%$ of baseline; $\mathrm{n}=12)$ and dnRAR H06 (137.2 $\pm 4.1 \%$ of baseline; $\mathrm{n}=10)$ mice. (D) LTP induced by single conditioning stimulation (one $100 \mathrm{~Hz}, 1 \mathrm{~s}$ train) in WT $(n=30)$ and dnRAR H06 $(n=16)$ mice. The initial EPSP slopes were measured, and the values were normalized in each experiment to the averaged slope value measured during the control period (-30 to 0 min). Conditioning stimulation was applied at $0 \mathrm{~min}$. The sample traces in the inset represent the EPSPs (average of 10 consecutive responses) of WT and H06 mice recorded at the times indicated by the letters. The stimulus artifacts were truncated. (E) Summary of LTP induced by single conditioning stimulation in WT and dnRAR H06 mice (21-30 min: WT, $149.5 \pm 2.0 \%$; H06, $143.9 \pm 3.5 \%$; 51-60 min: WT, $144.1 \pm 2.4 \%$; H06, $133.6 \pm 3.8 \%$; 111-120 min: WT, $133.3 \pm$ 2.9\%; H06, $118.6 \pm 3.6 \%$; 171-180 min: WT, $125.0 \pm 3.3 \%$; H06, $106.0 \pm 4.2 \%$ of baseline) ( $t$ test, $\left.{ }^{*} \mathrm{p}<0.05\right)$. (F) LTP induced by strong conditioning stimulation (four $100 \mathrm{~Hz}, 1 \mathrm{~s}$ trains at 5 min intervals) in WT $(n=6)$ and dnRAR H06 $(n=9)$ mice. The initial EPSP slopes were measured, and the values were normalized in each experiment to the averaged slope value measured during the control period (-30 to 0 min). Conditioning stimulation was applied at 0 min. The sample traces in the inset represent the EPSPs (average of 10 consecutive responses) of WT and H06 mice recorded at the times indicated by the letters. The stimulus artifacts were truncated. (G) Summary of normalized LTP induced by strong conditioning stimulation in WT and dnRAR H06 mice (21-30 min: WT, $181.4 \pm 3.6 \%$; H06, $179.2 \pm$ 3.9\%; 51-60 min: WT, 169.9 \pm 4.6\%; H06, 169.0 \pm 3.6\%; 111-120 min: WT, $155.3 \pm$ 5.3\%; H06, $151.9 \pm 5.5 \%$; 171-180 min: WT, $141.7 \pm 7.7 \%$; H06, $136.3 \pm 6.6 \%$ of baseline). (H) STP induced by short conditioning stimulation (one $100 \mathrm{~Hz}, 100 \mathrm{~ms}$ train) in WT (116.2 $\pm 5.1 \%$ of baseline; $n=5)$ and dnRAR H06 (120.6 $\pm 8.1 \%$ of baseline; $n=5)$ mice. The initial EPSP slopes were measured, and the values were normalized in each experiment to the averaged slope value measured during the control period (-30 to 0 min). Conditioning stimulation was applied at 0 min. Error bars indicate SEM. 
LTP (100 Hz for $1 \mathrm{~s})$. The magnitude of STP after induction was comparable between dnRAR H06 mice and WT littermates $(p>0.05)$. These observations suggest that dnRAR H06 mice displayed normal STP.

Taken together, our observations confirmed previous observations that dysfunction of the RAR/RXR signaling pathway results in impaired hippocampal LTP and extended these findings by demonstrating that this dysfunction also leads to an impaired AMPA receptormediated synaptic response. However, we could not exclude the possibility that impaired AMPA receptormediated EPSPs observed in dnRAR H06 mice contributed to the failure of LTP maintenance.

\section{Impaired social memory in dnRAR mice and its rescue by stronger training}

To investigate the effects of the impaired RAR/RXR signaling pathway on learning and memory, we performed a hippocampus-dependent social recognition memory task. This task measures the difference in the time taken to investigate a juvenile mouse by comparing between the first (training) and second (test) exposures to the mouse $[32,33]$. We first examined 2 h-short-term memory (STM; Figure 3A). Mice were exposed to a juvenile mouse for 1.5 min during the training and test sessions, which were performed $2 \mathrm{~h}$ apart. We measured the social investigation time of WT and OFF/ON-dnRAR H06 mice with the juvenile mouse during the training and test sessions and assessed the recognition index (i.e., the ratio of the social investigation time at the test relative to the training). One-way ANOVA with genotype (dnRAR and WT) revealed a significant effect of genotype $\left(\mathrm{F}_{(1,27)}=\right.$ 12.107, $\mathrm{p}<0.05)$. The post hoc Newman-Keuls test revealed that dnRAR H06 mice showed a significantly worse recognition index than the WT mice $(\mathrm{p}<0.05)$. Consistently, comparison of the social investigation time from the training and test sessions indicated that WT mice, but not OFF/ON-dnRAR H06 mice, displayed a significant decrease in social investigation time during the test compared to the training, indicating that WT mice formed STM, while OFF/ON-dnRAR H06 mice did not. These results indicated that OFF/ON-dnRAR H06 mice have impaired STM.

Our finding that the impaired LTP observed in OFF/ ON-dnRAR H06 mice was rescued by stronger conditioning stimulation raised the possibility that stronger training could also rescue the impaired STM in OFF/ ON-dnRAR H06 mice. To examine this, the mice were tested using a stronger training protocol in which they were exposed to a juvenile mouse for 3 min during the training and test sessions (Figure 3B) [33]. In contrast to the results shown above, one-way ANOVA revealed no significant effect of genotype $\left(\mathrm{F}_{(1,16)}=0.006, \mathrm{p}>0.05\right)$. Consistently, WT and OFF/ON-dnRAR H06 mice displayed a significant decrease in social investigation time during the test compared with the training, indicating that both groups formed STM. These observations indicated that stronger training rescued the impaired STM observed in dnRAR H06 mice.

We next examined the effects of dnRAR expression on the formation of long-term memory (LTM; Figure 3C). The mice were exposed to a juvenile mouse for $3 \mathrm{~min}$ during the training and test sessions, which were performed $24 \mathrm{~h}$ apart. In this experiment, OFF-dnRAR H06 mice that were administered Dox throughout their lifetime were also tested as a control group to clarify the effect of dnRAR expression. One-way ANOVA revealed an effect of group $\left(\mathrm{F}_{(2,68)}=7.992, \mathrm{p}<0.05\right)$. OFF/ONdnRAR H06 mice displayed a significantly worse recognition index than the WT and OFF-dnRAR H06 mice ( $\mathrm{p}<$ $0.05)$, which displayed comparable recognition indices ( $p>0.05)$. Consistently, the control groups $(\mathrm{p}<0.05)$, but not OFF/ON-dnRAR H06 mice ( $\mathrm{p}>0.05$ ), displayed significant decreases in social investigation time during the test compared with the training, indicating that the control groups formed LTM, while dnRAR H06 mice did not. These observations indicated that dnRAR H06 mice display impaired LTM in a dnRAR expression-dependent manner.

On the basis of our observations in the STM experiment, we examined whether a stronger training protocol rescues the impaired LTM observed in dnRAR H06 mice (Figure 3D). To do this, we used a spaced training protocol because a previous study demonstrated that the impaired LTM observed in mutant mice was rescued by a spaced, but not massed, training protocol [34]. The mice were trained with exposure to a juvenile mice for 3 min twice with an interval of 0 min (massed training), $10 \mathrm{~min}$, or $1 \mathrm{~h}$ (spaced training), and $24 \mathrm{~h}$ later, they were tested with exposure to the same juvenile mouse for 3 min (test). We assessed the recognition indices, i.e., the ratio of the social investigation time during the test relative to the first exposure during training. Two-way ANOVA with the duration of the interval (0 and $10 \mathrm{~min}$, and $1 \mathrm{~h}$ ) and genotype revealed an effect of genotype $\left(\mathrm{F}_{(1,67)}=11.930, \mathrm{p}<0.05\right)$, suggesting that, similar with the result shown in Figure 3C, dnRAR mice displayed impaired LTM. Consistently, the post hoc Newman-Keuls test revealed that massed-trained OFF/ON-dnRAR H06 mice displayed a significantly worse recognition index than the other groups $(\mathrm{p}<0.05)$, indicating that massedtrained dnRAR mice exhibited significantly impaired LTM. However, spaced-trained dnRAR mice (10 min or $1 \mathrm{~h}$ ) displayed a comparable recognition index with the other groups of WT mice ( $\mathrm{p}>0.05)$, suggesting that these groups of spaced-trained mutant mice exhibited normal LTM. Consistently, although all groups displayed significant decreases in social investigation time during 


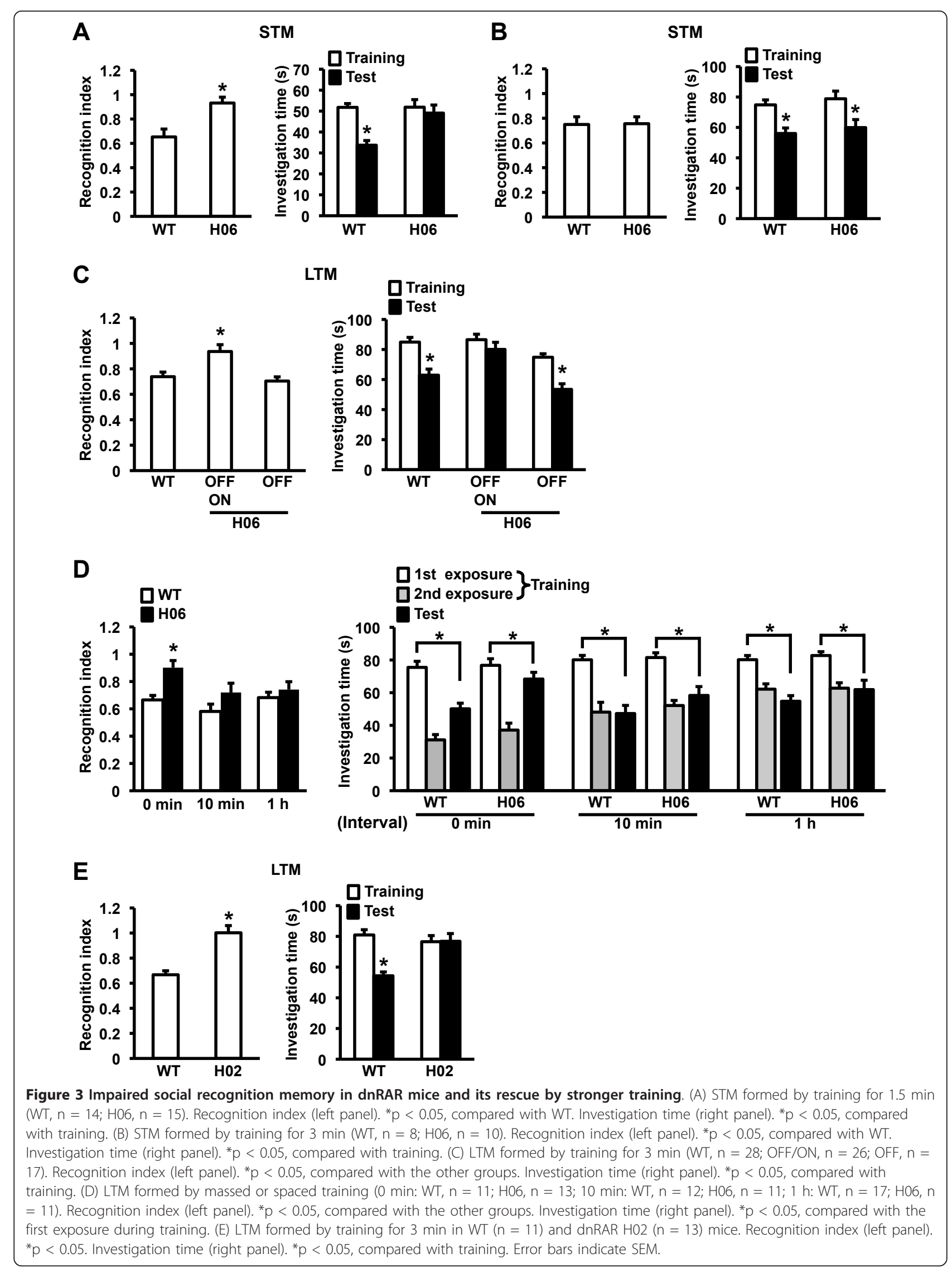


the test compared with the first exposure during training $(\mathrm{p}<0.05)$, massed-trained OFF/ON-dnRAR H06 mice displayed a significant, but small, decrease in their social investigation time. These observations indicated that the impaired LTM observed in OFF/ON-dnRAR H06 mice was rescued by spaced, but not massed, training with an interval of $10 \mathrm{~min}-1 \mathrm{~h}$.

We also performed a social recognition test using another transgenic line (dnRAR H02 mice) that displays higher expression levels of dnRAR (Figure 3E). The mice were trained and then tested $24 \mathrm{~h}$ later with exposure to a juvenile mouse for $3 \mathrm{~min}$. Consistent with the result for dnRAR H06 mice, one-way ANOVA revealed a significant effect of genotype $\left(F_{(1,22)}=23.568, \mathrm{p}<0.05\right)$. OFF/ONdnRAR-H02 mice showed a significantly worse recognition index than WT mice $(\mathrm{p}<0.05)$. Consistently, WT, but not OFF/ON-dnRAR H02, mice exhibited a significant decrease in social investigation time during the test compared with training ( $p>0.05)$. These observations confirmed that the expression of dnRAR in the forebrain leads to impaired social recognition memory.

Taken together, our observations indicated that dnRAR mice have impaired ST- and LT-social recognition memories. Importantly, these memory impairments are rescued by stronger training.

\section{Impaired spatial memory in dnRAR mice and its rescue by stronger training}

To examine whether the memory impairment caused by dnRAR expression can be generalized to other hippocampus-dependent memories formed by different sensory, motivational, and performance demands, we performed the Morris water maze test. In this task, the mice formed a spatial memory of the position of a hidden platform in a swimming pool using spatial cues around the pool. The mice were trained with 2 trials at 1 min intervals per day for 7 days (Figure 4A). Two-way repeated ANOVA with genotype (WT and dnRAR) and time (days 1-7) revealed significant effects of genotype and time (genotype, $\mathrm{F}_{(1,26)}$ $=25.402, \mathrm{p}<0.05$; time, $\left.\mathrm{F}_{(6,156)}=23.833, \mathrm{p}<0.05\right)$. The post hoc Newman-Keuls test revealed that OFF/ONdnRAR H06 mice displayed significantly longer escape latencies than WT mice at days 2-7. These results indicated that dnRAR H06 mice displayed a worse performance during training than WT mice. To examine the formation of spatial memory, we performed a probe test at day 8 after training for 7 days. In the probe test, the mice were allowed to swim for $60 \mathrm{~s}$, and we assessed the time spent in each quadrant of the pool (Figure 4A). Planned comparisons using a paired $t$ test revealed that WT mice spent significantly more time in the target quadrant (TQ) compared with the other quadrants [TQ vs. opposite (OP), adjacent right (AR), or adjacent left (AL); $\mathrm{p}<0.05$ ], while OFF/ON-dnRAR H06 mice did not
( $\mathrm{p}>0.05)$, indicating that only WT mice formed spatial memory. These observations indicated that OFF/ONdnRAR H06 mice have impaired spatial memory.

On the basis of the observations in the social recognition task, it is possible that spaced training could rescue the impaired memory performance observed in dnRAR H06 mice. To examine this, the mice were trained with 2 trials at $1 \mathrm{~h}$ intervals per day for 7 days (Figure 4B). In contrast to the previous results, two-way repeated ANOVA revealed a significant effect of time, but not genotype (genotype, $\mathrm{F}_{(1,25)}=2.872, \mathrm{p}>0.05$; time, $\mathrm{F}_{(6,150)}$ $=46.768, \mathrm{p}<0.05)$, indicating that both groups of mice displayed a comparable improvement of memory performance as both groups showed decreases in escape latency with training days. Consistently, the results of the probe test revealed that WT and OFF/ON-dnRAR H06 mice spent significantly more time in the TQ compared with the other quadrants, indicating that both groups formed spatial memory. These results indicated that the impaired spatial memory observed in OFF/ON-dnRAR H06 mice was rescued by spaced training. Collectively, these observations indicated that OFF/ON-dnRAR H06 mice have a deficit in spatial memory, but this deficit is rescued by stronger training, and confirmed our findings in the social recognition task.

It is important to note that WT and OFF/ON-dnRAR H06 mice showed normal locomotor activity and anxiety-related behaviors (time spent in the center of field) in the open field test (Additional file 1, Figure S1). Furthermore, OFF/ON-dnRAR H06 mice displayed normal swim speed (Additional file 2, Figure S2) and social investigation time during the training session in social recognition test (Figure 3), compared to WT mice. These observations strongly suggest that memory impairments observed in dnRAR mice does not attribute to abnormal locomotor and/or emotional behaviors such as social and anxiety-related behaviors.

\section{Pharmacological loss-of-function of hippocampal RAR $\alpha$ impairs social recognition memory}

Our observations that dnRAR expression in the forebrain led to impairments of hippocampal synaptic transmission and plasticity and the formation of two different types of hippocampus-dependent memories suggest that the RAR/ RXR signaling pathway plays a crucial role in hippocampus-dependent memory. To further understand the roles of RAR $\alpha$ in the hippocampus, we examined the effects of the pharmacological blockade of RAR $\alpha$ in the hippocampus on LT-social recognition memory using a micro-infusion of Ro41-5253 (Ro41), a selective antagonist of RAR $\alpha$, into the dorsal hippocampus. WT mice were trained and tested $24 \mathrm{~h}$ later with exposure to a juvenile mouse for 3 min. The mice received a micro-infusion of vehicle $(\mathrm{VEH})$ or Ro41 (242 pg/side) into the dorsal hippocampus at 1, 4, 


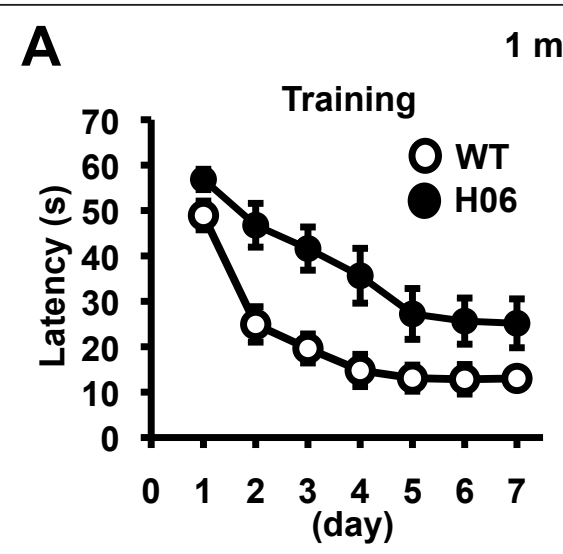

\section{1 min interval}

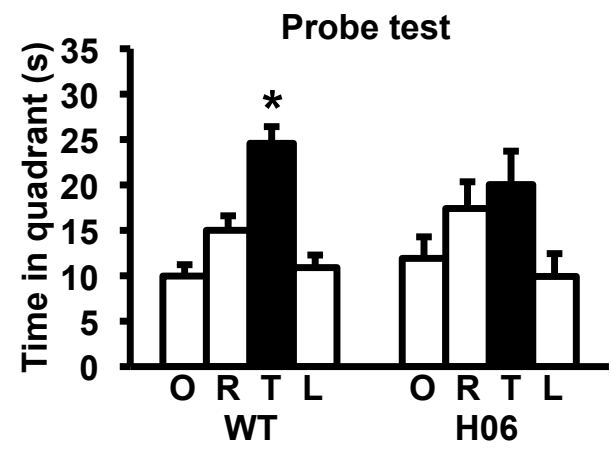

B

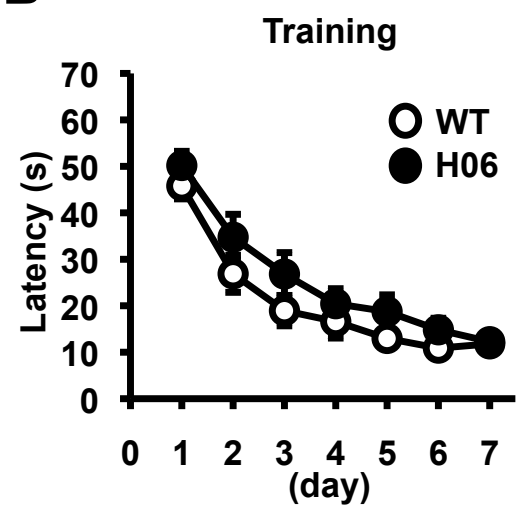

$1 \mathrm{~h}$ interval

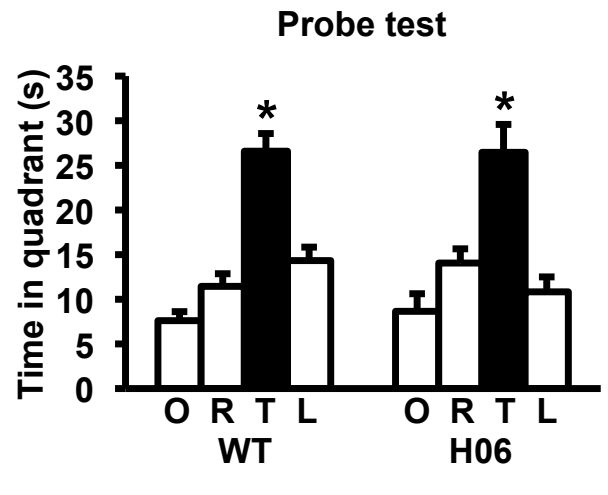

Figure 4 Impaired spatial memory in dnRAR mice and its rescue by spaced training. (A) Escape latencies during training with a 1 min interval (left panel; $W T, n=18 ; H 06, n=12$ ). Data are indicated in blocks of 2 trials. Probe test at day 8 (right panel). ${ }^{*} p<0.05$ compared with the other 3 quadrants. (B) Escape latencies during training with a $1 \mathrm{~h}$ interval (left panel; $W T, n=15 ; H 06, n=12$ ). Data are indicated in blocks of 2 trials. Probe test at day 8 (right panel). ${ }^{*} p<0.05$ compared with the other 3 quadrants. Error bars indicate SEM.

or $24 \mathrm{~h}$, respectively, before training (Figure $5 \mathrm{~A}$ ). One-way ANOVA revealed a significant effect of group $\left(\mathrm{F}_{(3,53)}=\right.$ 5.460, $\mathrm{p}<0.05)$. The mice infused with Ro41 at $4 \mathrm{~h}$ before training displayed a significantly worse recognition index than the other groups $(\mathrm{p}<0.05)$, which displayed comparable recognition indices $(\mathrm{p}>0.05)$. Consistently, the mice infused with Ro41 at $4 \mathrm{~h}$ before training failed to decrease their social investigation time during the test compared with training, while the other groups displayed significant decreases in their social investigation time. These observations indicated that the microinfusion of Ro41 into the hippocampus impairs social recognition memory within a time window that impairs memory performance. We also examined the dose-dependent effects of Ro41 on the impairment of LT-social recognition memory. WT mice received a low-dose microinfusion of Ro41 (24 pg/side) into the dorsal hippocampus at $4 \mathrm{~h}$ before training. Oneway ANOVA with drug (VEH and the low and high dose groups) revealed a significant effect of group $\left(\mathrm{F}_{(2,41)}=\right.$ $8.046, \mathrm{p}<0.05)$. The mice that received a high dose of Ro41 displayed a significantly worse recognition index than the VEH group $(\mathrm{p}<0.05)$, whereas the mice that received a low dose of Ro41 displayed a comparable recognition index with the mice infused with $\mathrm{VEH}$ or a high dose of Ro41 ( $p>0.05$ ). Consistently, the mice that were infused with a low dose of Ro41 displayed a significant decrease in social investigation time during the test compared with training, while the mice infused with a high dose of Ro41 did not. These observations indicated that the micro-infusion of Ro41 into the hippocampus impairs social recognition memory in a dose-dependent manner. Collectively, our observations indicated that the blockade of RAR $\alpha$ in the hippocampus impairs social recognition memory, suggesting that the RAR/RXR signaling pathway in the hippocampus is crucial for social recognition memory.

\section{Discussion}

In this study, we characterized the roles of the RAR/ RXR signaling pathway in the forebrain during learning and memory. To do this, we generated conditional mutant mice in which the expression of dnRAR was 

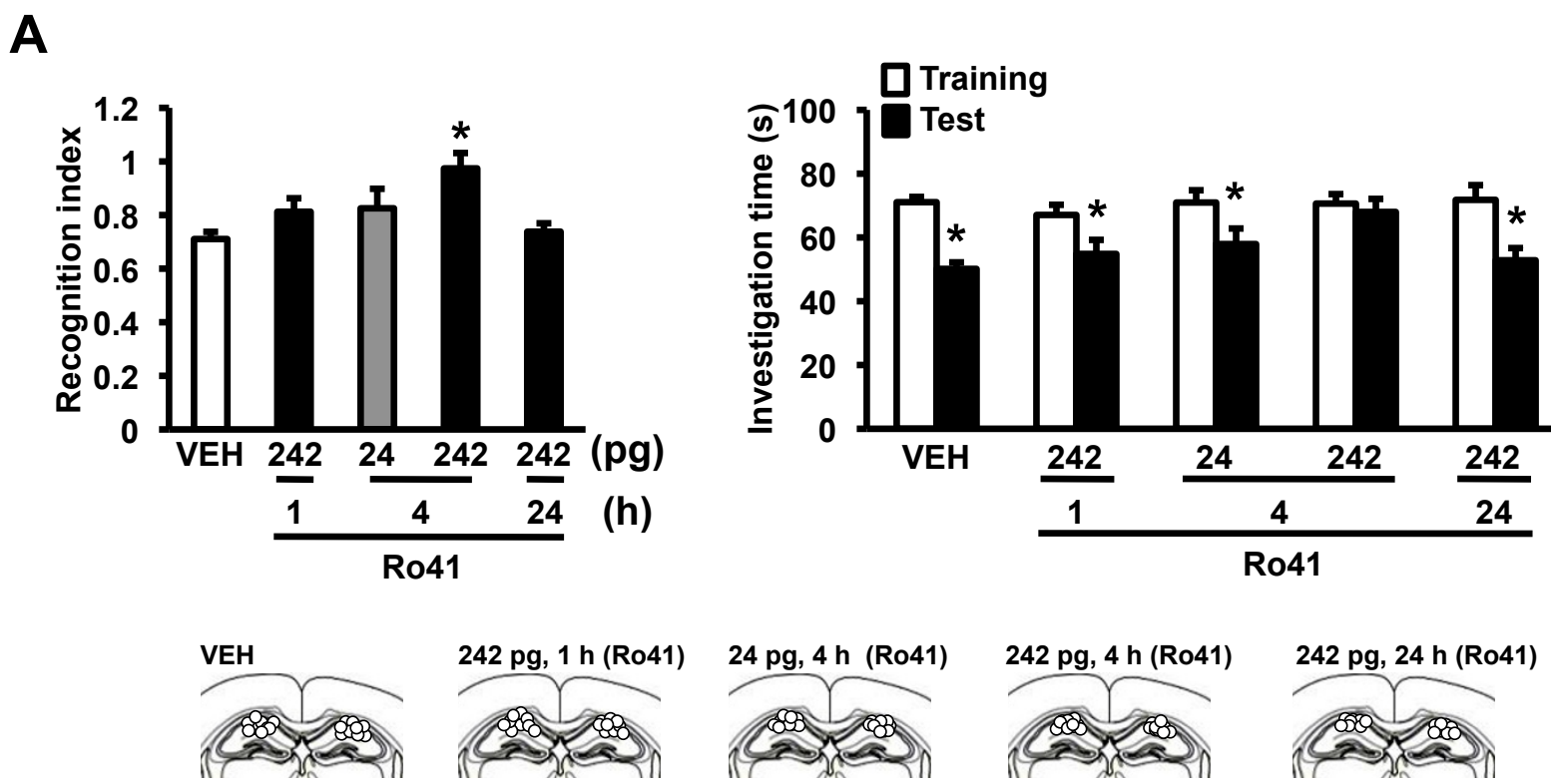

Figure $\mathbf{5}$ Impaired social recognition memory by the pharmacological inhibition of hippocampal RAR $\boldsymbol{\alpha}$. Recognition index (left panel) Effects of micro-infused Ro41-5253 (Ro41; 242 pg/side) into the dorsal hippocampus at 1, 4, or $24 \mathrm{~h}$ before training and the effects of microinfused low-dose Ro41 (24 pg/side) on 24 h LT-social recognition memory (VEH, $\mathrm{n}=38 ; 1 \mathrm{~h}, \mathrm{n}=12 ; 4 \mathrm{~h}$-low, $\mathrm{n}=11 ; 4 \mathrm{~h}, \mathrm{n}=13 ; 24 \mathrm{~h}, \mathrm{n}=12$ ). ${ }^{*} p<0.05$, compared with the VEH group. Investigation time (right panel). ${ }^{*} p<0.05$, compared with training. The lower panel indicates cannula tip placement in mice infused with VEH or Ro41.

induced only in the forebrain of adult mice using a tetracycline-dependent transcription factor expression system. These mutant mice induced dnRAR expression in a Dox-dependent manner and down-regulated RAR $\beta$ gene expression, a target gene of RAR/RXR, in a dnRAR expression-dependent manner, suggesting that these mutant mice only display a dysfunction of the RAR/ RXR signaling pathway in the forebrain when dnRAR is expressed. Similarly with previous findings, these dnRAR mice displayed impaired LTP, especially the maintenance of LTP in the hippocampus; however, this deficit of LTP was rescued by stronger stimulation. Furthermore, we observed an impaired AMPA receptormediated synaptic response in dnRAR mice. These findings suggest that the dysfunction of the RAR/RXR signaling pathway impairs synaptic transmission as well as potentiation in the hippocampus. Conversely, dnRAR mice displayed deficits in ST- and LT-social recognition memory without an effect on immediate memory (see Figure 3D). Interestingly, these impairments of STM and LTM in the dnRAR mice were rescued by stronger or spaced training, respectively. Consistently, dnRAR mice displayed normal spatial learning and memory in the Morris water maze when they were spaced trained, but not when they were massed trained. Furthermore, pharmacological inhibition of RAR $\alpha$ in the hippocampus impaired social recognition memory. These behavioral observations suggest that the RAR/RXR signaling pathway plays critical roles in hippocampus-dependent memory. Taken together, our observations strongly suggest that the RAR/RXR signaling pathway is required for synaptic transmission and plasticity and learning and memory in the forebrain, especially the hippocampus.

Memory consolidation is a process that generates LTM [35-37]. Previous studies have shown that the inhibition of gene expression blocks the formation of LTM without affecting STM [38-40]. Indeed, the activation of CREBmediated transcription plays an essential role in memory consolidation and LTP [33,39]. In this study, we showed that dysfunction of the RAR/RXR signaling pathway impairs STM and LTM. These observations suggest that RAR/RXR play distinct roles from CREB in hippocampus-dependent memory; it is unlikely that RAR/RXR greatly contribute to memory consolidation via learninginduced RAR/RXR-mediated transcription, as CREB does. Indeed, our finding that loss of RAR/RXR function impairs not only LTP but also the AMPA receptormediated synaptic response raises the possibility that RAR/RXR contribute to leaning/memory via basal synaptic transmission as well as long-term plasticity.

Interestingly, we observed that RAR/RXR dysfunction impaired the hippocampal LTP induced by a single conditioning stimulus and hippocampus-dependent social and spatial memories. However, stronger stimulation (four conditioning stimuli) and stronger or spaced training rescued these impairments in LTP and memories, 
respectively. The similarity of the observations at the cellular and behavioral levels strongly suggests the importance of the RAR/RXR signaling pathway in the hippocampus for both plasticity and learning and memory. Furthermore, this importance is supported by our observations that the pharmacological inhibition of RAR $\alpha$ function in the hippocampus blocked the formation of social recognition memories. Further studies are required to examine the correlation between synaptic plasticity and learning/memory ability in the hippocampus of dnRAR mice, and the roles of RAR-mediated long-term plasticity in memory performance.

Recent reports have shown that RAR $\alpha$ is present in the dendrites located in the hippocampus and induces the translation of GluA1 in a RA-dependent manner, resulting in the increased membrane insertion of GluA1 [41,42]. Interestingly, this regulation of GluA 1 by RAR $\alpha$ is independent of transcriptional regulation $[42,43]$. In the absence of RA, cytoplasmic RAR $\alpha$ directly binds with GluA1 mRNA localized in dendrites via its C-terminal Fdomain and represses its translation [44]. In the presence of RA, RA binding to RAR $\alpha$ releases the GluA1 mRNA that is trapped by RAR $\alpha$, leading to the translational activation of GluA1 [44]. The dominant-negative mutant of RAR $\alpha$ used in this study lacks the $\mathrm{C}$-terminus, including the $\mathrm{F}$-domain that is required for its interaction with GluA1 mRNA [26]. Therefore, it is possible that the dnRAR used in this study not only inhibits RAR/RXRmediated transcription but also affects the translational regulation of GluA1. dnRAR might block the RA-dependent release of GluA1 mRNA in dendrites by trapping RA and inhibiting the translational activation of GluA1 mRNA, resulting in the down-regulation of AMPAmediated synaptic transmission.

The findings in this and other studies showed that the dysfunction of RAR/RXR leads to impairments of memory and LTP in the hippocampus [18-20]. Conversely, previous studies have suggested that the age-related down-regulation of RAR/RXR-mediated gene expression is implicated in the cognitive decline of aged mice $[16,17]$. Importantly, these studies demonstrated that the administration of RA alleviates the down-regulated expression of RA-target genes in the hippocampus, agerelated deficits in hippocampal LTP, and memory performance. Furthermore, the administration of RA prevents the deposition of $A \beta$ and rescues memory deficits in a transgenic mouse model of Alzheimer' disease [45]. Taken together, these observations raise the possibility that the RAR/RXR signaling pathway positively regulates memory performance and, moreover, that the activation of this signaling pathway improves learning and memory. Further studies are required to examine the effects of gain of RAR/RXR function on learning and memory by the genetic enhancement of RAR/RXR.
A previous genetic study showed that the deletion of the RAR $\beta$ or RAR $\beta / R X R \gamma$ genes leads to disrupted LTP and LTD in the CA1 region of the hippocampus without affecting basal synaptic transmission [18]. In contrast, our results indicated that dysfunction of the RAR/RXR signaling pathway by the expression of dnRAR impairs the maintenance, but not induction, of CA1-LTP and the AMPA receptor-mediated synaptic response. The differences between these two studies may reflect distinct roles of RAR/RXR subtypes in synaptic transmission and potentiation in the hippocampus $[6,46]$. Additionally, there is a possibility that the protocols used to induce LTP contributed to the different findings of these two studies.

In summary, we found that dysfunction of the RAR/ RXR signaling pathway leads to the down-regulation of RAR $\beta$ expression and impairment of AMPA-mediated synaptic transmission and LTP in the hippocampus and hippocampus-dependent social recognition and spatial memories. More interestingly, stronger conditioning stimulation and training rescued these impairments of LTP and memory performance, respectively. Furthermore, we showed that blocking the function of RAR $\alpha$ in the hippocampus disrupted social recognition memory. These observations strongly suggested that the RAR/RXR signaling pathway in the hippocampus plays critical roles in synaptic plasticity and memory performance.

\section{Materials and methods}

Mice

Mice were housed in cages of 5 or 6 , maintained on a 12 $\mathrm{h}$ light/dark schedule, and allowed ad libitum access to food and water in their home cages. All of the experiments were conducted during the light phase of the cycle in an illuminated testing room according to the Guide for the Care and Use of Laboratory Animals, Japan Neuroscience Society and Tokyo University of Agriculture. All of the experiments were conducted blind to the treatment condition of the mouse. Animal behavior was recorded using a video camera.

\section{Plasmid construction}

Generation of the dominant-negative RAR $\alpha$ mutant (dnRAR) lacking the C-terminal region of RAR $\alpha$ (aa 403462) was performed as described previously [26]. To generate dnRAR cDNA, 2 separate fragments of the dnRAR cDNA (nucleotides 1-438 and 433-1206) were amplified by reverse transcription-polymerase chain reaction (RTPCR) using mouse brain CDNA as a template with the following primers: $1 / 438$ primers (sense, gggggatccagatctatggccagcaatagcagttc; antisense, ggggaattcctgcagccggc agtactggc); 433/1209 primers (sense, gggggatcctgcagaa atgtttcgacgt; antisense, ggggaattcacgcgtaagctttcagatctccatcttcaatg; the termination codon to generate dnRAR is 
underlined). The resulting RT-PCR fragments were subcloned into the BamHI-EcoRI sites of pBluescript II $(\mathrm{SK}+)$ (Agilent Technologies, CA, USA), generating pBS-dnRAR. The BglII-HindIII fragment encoding dnRAR from pBSdnRAR was ligated with the BglII-HindIII fragment from pTRE-dnBMAL1 [27], generating pTRE-dnRAR.

\section{Generation of transgenic mice}

pTRE-dnRAR was digested with MluI, and transgenic mice were generated by injecting the purified insert into the pronuclei of C57BL/6N zygotes. TRE-dnRAR founders were crossed with C57BL/6N mice (Charls River Japan, Kanagawa, Japan). These founders were crossed with mice (CaMKII-tTA) expressing the tTA transgene under the control of the $\alpha$ CaMKII promoter [24], generating double-transgenic mice (dnRAR TgM). Genotyping was performed by Southern blot analysis using specific probes derived from the $0.5 \mathrm{kbp}$ NotI-NdeI fragment containing the TRE-promoter region from pcisTRE [27] and the $0.6 \mathrm{kbp}$ EcoRI-HindIII fragment containing the tTA-coding region from pcDNA3-TetR-KRAB [27].

\section{Administration of doxycycline}

TRE promoter-dependent transgene expression was regulated using the animal's drinking water containing 1 $\mu \mathrm{g} / \mathrm{mL}$ doxycycline (Dox) (Sigma, MO, USA) dissolved in $5 \%$ sucrose to mask the bitter taste of Dox.

\section{Biochemical experiments}

Northern blot analysis was performed as described previously $[39,47]$. Total RNA was prepared as described previously $[39,47]$. To generate a specific probe for TRE promoter-dependent transcripts, the $0.3 \mathrm{kbp}$ HindIIIXbaI fragment containing the 3'-UTR from pTREdnRAR was used. The filters were hybridized with a specific probe for the 3'-UTR and then re-hybridized with GAPDH cDNA as an internal control. qRT-PCR was performed as described previously [47]. qRT-PCR was performed on an ABI PRISM 7000 using the Power SYBR Green PCR Master Mix (Applied Biosystems, CA, USA) according to the manufacturer's protocol. The reaction was first incubated at $50^{\circ} \mathrm{C}$ for $2 \mathrm{~min}$, then at $95^{\circ} \mathrm{C}$ for $10 \mathrm{~min}$, followed by 40 cycles of $95^{\circ} \mathrm{C}$ for $15 \mathrm{~s}$ and $60^{\circ} \mathrm{C}$ for $1 \mathrm{~min}$. All measurements were performed in triplicate. The levels of GAPDH mRNA were used to normalize the relative expression levels of target mRNA. The PCR primers used were as follows (5' to 3'): RAR $\beta$ forward, tcctggatcaatgccacctc; RAR $\beta$ reverse, acacgctggactgtgctct; GAPDH forward, atggccttccgtgttcctac; and GAPDH reverse, gcctgcttcaccaccttctt. Western blot analysis using a rabbit polyclonal anti-HA antibody (1:1000; Santa Cruz Biotechnology, CA, USA) and a mouse monoclonal anti- $\alpha$-tubulin antibody (1:1000; Santa Cruz Biotechnology, CA, USA) was performed as described previously $[48,49]$. Equal protein loading was confirmed by reprobing with the anti- $\alpha$-tubulin antibody. The protein bands were detected using the ImmunoStar LD system (Wako, Osaka, Japan) according to the manufacturer's protocol, and the chemiluminescence signals were analyzed with the ChemiDoc XRS detection system and QuantityOne software (Bio-Rad Laboratories, CA, USA).

\section{Behavioral experiments}

Before the commencement of the behavioral experiments, the mice were individually handled for $2 \mathrm{~min}$ each day for 1 week. Individual mice were used for all experiments.

\section{Social recognition test}

The social recognition test was performed as described previously $[32,33]$. Adult mice were placed into individual plastic cages in an experimental room under dim light. The cages were identical to those in which mice were normally housed (plastic, $30 \times 17 \times 12 \mathrm{~cm}$ ). After a period of $60 \mathrm{~min}$, a juvenile mouse was placed into a cage with a subject for a training trial that lasted for $1.5 \mathrm{~min}$ (see Figure 3A) or 3 min (see Figures 3B, C, E, 5A). The duration of social investigation behavior exhibited by the adult mouse was determined using a hand-held stopwatch. Social investigation was measured as described previously [50]. Memory was reassessed at $2 \mathrm{~h}$ or $24 \mathrm{~h}$ later by recording the length of the investigation time exhibited by the subject to the same juvenile (test). To evaluate the differences in the ability to form social memory between the groups of mice, we calculated a recognition index, i.e., the ratio of the duration of the second and first investigation times. When massed or spaced training was performed, the subjects were trained with 2 trials lasting $3 \mathrm{~min}$ at intervals of $0 \mathrm{~min}$ (massed-training) and $10 \mathrm{~min}, 1 \mathrm{~h}$ (spaced training) on the first trial day. Memory was reassessed at $24 \mathrm{~h}$ after the training as described above. The recognition index was calculated as the ratio of the social investigation time during the test relative to the first exposure during training.

\section{Morris water maze test}

The Morris water maze test was performed as described previously $[33,40,51]$. The mice were trained with 2 trials at intervals of $1 \mathrm{~min}$ (see Figure $4 \mathrm{~A}$ ) or $1 \mathrm{~h}$ (see Figure 4B) per day for 7 days. The mice were tested at approximately the same time everyday. In the probe test at $24 \mathrm{~h}$ after $7 \mathrm{~d}$ of training, the platform was removed, and the mice were allowed to swim for $60 \mathrm{~s}$. We measured the time that the mice spent in each quadrant.

\section{Surgery for drug microinfusion}

Surgery was performed as described previously [51-54]. Under Nembutal anesthesia and using standard 
stereotaxic procedures, stainless steel guide cannulae (22 gauge) were implanted into the dorsal hippocampus (-1.8 mm, $\pm 1.8 \mathrm{~mm},-1.9 \mathrm{~mm}$ ). Ro41-5253 (Ro41) (Enzo Life Sciences, NY, USA), an RAR $\alpha$-selective antagonist, was dissolved in dimethyl sulfoxide (DMSO) (Wako, Osaka, Japan), and then dissolved in vehicle solution (VEH) [artificial CSF (ACSF)] with a final DMSO concentration of $0.01 \%$. Micro-infusions into each brain region $(0.5 \mu \mathrm{L})$ were made at a rate of $0.25 \mu \mathrm{L} / \mathrm{min}$. The injection cannula was left in place for $2 \mathrm{~min}$ after the infusion.

\section{Electrophysiology}

Electrophysiology was performed as described previously $[30,55]$. All experiments were performed to compare dnRAR mice with WT mice in a blind fashion using littermates. Three- to 5-month-old dnRAR and WT mice were decapitated under deep halothane anesthesia, and both hippocampi were removed. Hippocampal slices (400- $\mu$ m thick) were cut with a Vibratome tissue slicer and placed in a humidified interface-type chamber for at least $1 \mathrm{~h}$. A single slice was then transferred to the recording chamber, which was maintained at $25^{\circ} \mathrm{C}$, and submerged beneath a continuously perfusing medium (119 mM NaCl, $2.5 \mathrm{mM} \mathrm{KCl,} 1.3 \mathrm{mM} \mathrm{MgSO}$, $2.5 \mathrm{mM}$ $\mathrm{CaCl}_{2}, 1.0 \mathrm{mM} \mathrm{NaH} \mathrm{PO}_{4}, 26.2 \mathrm{mM} \mathrm{NaHCO}$, and 11 $\mathrm{mM}$ glucose) that had been saturated with $95 \% \mathrm{O}_{2}$ and $5 \% \mathrm{CO}_{2}$. All perfusing solutions contained picrotoxin $(100 \mu \mathrm{M})$ to block gamma-aminobutyric acid A receptor (GABA-A-R)-mediated inhibitory synaptic responses. Field potential recordings were made using a glass electrode filled with $3 \mathrm{M} \mathrm{NaCl}$ and placed in the stratum radiatum of the hippocampal CA1 region.

To evoke synaptic responses, a bipolar stimulating tungsten electrode was placed in the stratum radiatum, and Schaffer collateral/commissural fibers were stimulated at $0.1 \mathrm{~Hz}$ (test pulses). An Axopatch 200B amplifier (Molecular Devices, Sunnyvale, USA) was used, and the signal was filtered at $1 \mathrm{kHz}$ and digitized at $10 \mathrm{kHz}$, and stored on a personal computer. The stimulus strength was adjusted so that it gave rise to AMPA receptor-mediated EPSPs with a slope value between 0.10 and $0.15 \mathrm{mV} / \mathrm{ms}$. For the analysis of EPSPs, we measured their early rising phase to avoid contamination from voltage-dependent components as much as possible. Each data point represents the averaged slope value for $1 \mathrm{~min}$ that was normalized to the baseline slope value. For LTP recording, LTP was induced using 1 or 4 high-frequency stimulations (one $100 \mathrm{~Hz}, 1 \mathrm{~s}$ train or four $100 \mathrm{~Hz}, 1 \mathrm{~s}$ trains at $5 \mathrm{~min}$ intervals, respectively). For STP recording, STP was induced using a single high-frequency stimulation (one $100 \mathrm{~Hz}, 100$ ms train). To record the input-output relationships, D2-amino-5-phosphonovaleric acid (D-APV, $25 \mu \mathrm{M}$ ) was present to block $\mathrm{N}$-methyl-D-aspartate receptor (NMDA-R)-mediated synaptic responses. A low concentration of 6-cyano-7-nitro-quinoxaline-2,3-dione (CNQX, $1 \mu \mathrm{M}$ ) was also present to partially block alpha-amino-3-hydroxy-5-methyl-4-isoxazole propionate receptor (AMPA-R)-mediated synaptic responses because the fiber volleys were usually much smaller than the EPSPs. This enables more accurate measurements of the input-output relationships, since the presence of low concentrations of CNQX reduces the nonlinear summation of field EPSPs when strong stimulus strengths are used. For the measurement of PPF, afferent fibers were stimulated twice at intervals of 50 , 100,200 , and $300 \mathrm{~ms}$ in the presence of D-APV (25 $\mu \mathrm{M})$. For PTP recordings, PTP was induced using a single high-frequency stimulation (one $100 \mathrm{~Hz}, 1 \mathrm{~s}$ train) in the presence of D-APV $(50 \mu \mathrm{M})$. Data were collected using Clampex 5.0 and analyzed with pClamp 9.0 software. Picrotoxin and D-APV were purchased from Sigma (MO, USA) and CNQX was purchased from Tocris Cookson (Avonmouth, UK).

\section{Data analysis}

Data were analyzed with ANOVA. One-way ANOVA analysis followed by the post hoc Newman-Keuls comparison was used to analyze the effects of genotype, time, and drug. Two-way ANOVA analysis followed by the post hoc Newman-Keuls comparison was used to analyze the effects of genotype, time, and duration of the interval. All values in the text and figure legends represent the mean \pm SEM. A paired $t$ test was used to analyze the differences in the social investigation times within each group between training and test in the social recognition test, and to analyze the differences of the time spent in the TQ compared with the other quadrants in the Morris water maze test. Student's $t$ test (two-tailed, unpaired) was used to determine whether there was a significant difference in the means between two sets of data in the electrophysiological experiments.

\section{Additional material}

\footnotetext{
Additional file 1: Figure S1. Locomotion and anxiety-related behaviors of dnRAR mice in the open field test. The open field test was performed as described previously [47]. Mice were placed into the center of a square open field chamber $(40 \mathrm{~cm}$ long $\times 40 \mathrm{~cm}$ wide $\times 40$ $\mathrm{cm}$ high) that was surrounded by white acrylic walls. The total length of the path mice traveled (locomotor activity) and the time they spent in a center square $(24 \mathrm{~cm} \times 24 \mathrm{~cm} ; \%$ center) were measured over the course of 5 min using an automatic monitoring system (Neuroscience Inc., Tokyo, Japan). (A) The total path length for $5 \mathrm{~min}$. (B) The percent of time spent in the center for $5 \mathrm{~min}$. WT $(n=8)$ and OFF/ON-dnRAR H06 mice $(n=8)$ showed comparable total path and percentage of time spent in the center of the field (one-way ANOVA; locomotor activity, $F$ $(1,14)=0.035, P>0.05 \%$ center, $\left.F_{(1,14)}=0.597, P>0.05\right)$. These results suggested that OFF/ON-dnRAR H06 mice display normal locomotor activity and anxiety-related behaviors. Error bars are SEM.
} 
Additional file 2: Figure S2. Comparison of swim speed between WT and dnRAR mice. Mice were allowed to swim in the pool used in Morris water maze test. The total length of the path for 1 min (total path) using an automatic monitoring system (Neuroscience Inc., Tokyo, Japan) and then swim speed was calculated. WT $(n=11)$ and OFF/ON dnRAR H06 $(n=15)$ mice showed comparable swim speed (one-way ANOVA; $\left.F_{(1,24)}=0.023, P>0.05\right)$. Error bars are SEM.

\section{List of abbreviations}

tTA: tetracycline-controlled transactivator; aCaMKIl: a-calcium/calmodulindependent protein kinase II.

\section{Acknowledgements}

S.K. was supported by Grant-in-Aids for Scientific Research (B) (23300120 and 20380078) and (C) (18580129), Grant-in-Aids for Scientific Research on Priority Areas -Molecular Brain Science- (18022038 and 22022039), High Technology Research and from the Ministry of Education, Culture, Sports, Science, and Technology, Japan, Core Research for Evolutional Science and Technology (CREST), Japan, a Research Grant for Nervous and Mental Disorders from the Ministry of Health, Labor, and Welfare, Japan, 4th Itsuu Laboratory Research Grant, Japan, The Sumitomo Foundation, Japan and the Takeda Science Foundation, Japan.

\section{Author details}

'Department of Bioscience, Faculty of Applied Bioscience, Tokyo University of Agriculture, Tokyo 156-8502, Japan. ${ }^{2}$ Core Research for Evolutional Science and Technology, Japan Science and Technology Agency, Saitama 332-0012, Japan. ${ }^{3}$ Division of Neuronal Network, Department of Basic Medical Sciences, Institute of Medical Science, University of Tokyo, Tokyo 108-8639, Japan. ${ }^{4}$ Laboratory of Neurophysiology, Department of Neuroscience, Jikei University School of Medicine, Minato-ku, Tokyo 105-8461, Japan; Precursory Research for Embryonic Science and Technology, Japan Science and Technology Agency, Kawaguchi, Saitama 332-0012, Japan.

\section{Authors' contributions}

SKida is responsible for the hypothesis development and overall design of the research and experiment, and supervised the experimental analyses. SKida and MNomoto co-wrote the manuscript. MNomoto performed biochemical and electro-physiological analyses. YTakeda, HEnomoto, and TChoi performed behavioral analyses. SUchida constructed a transgene and generated transgenic mice expressing dnRAR. KMitsuda and KSaito performed treatment of doxycycline. AM. Watabe, SKobayashi, SMasushige, and TManabe supervised experimental analyses. All authors read and approved this manuscript.

\section{Competing interests}

The authors declare that they have no competing interests.

Received: 5 January 2012 Accepted: 8 February 2012

Published: 8 February 2012

\section{References}

1. Mangelsdorf DJ: Vitamin A receptors. Nutr Rev 1994, 52:S32-44.

2. Sucov HM, Evans RM: Retinoic acid and retinoic acid receptors in development. Mol Neurobiol 1995, 10:169-184.

3. Napoli JL: Retinoic acid biosynthesis and metabolism. FASEB J 1996, 10:993-1001

4. Chambon P: A decade of molecular biology of retinoic acid receptors. FASEB J 1996, 10:940-954

5. Evans RM: The steroid and thyroid hormone receptor superfamily. Science 1988, 240:889-895.

6. Mangelsdorf DJ, Thummel C, Beato M, Herrlich P, Schütz G, Umesono K, Blumberg B, Kastner P, Mark M, Chambon P, Evans RM: The nuclear receptor superfamily: the second decade. Cell 1995, 6:835-839.

7. McCaffery P, Zhang J, Crandall JE: Retinoic acid signaling and function in the adult hippocampus. J Neurobio/ 2006, 7:780-791.
8. Gofflot F, Chartoire N, Vasseur L, Heikkinen S, Dembele D, Le Merrer J, Auwerx J: Systematic gene expression mapping clusters nuclear receptors according to their function in the brain. Cell 2007, 2:405-418.

9. Goodman AB: Three independent lines of evidence suggest retinoids as causal to schizophrenia. Proc Natl Acad Sci USA 1998, 13:7240-7244.

10. Goodman $A B$, Pardee $A B$ : Evidence for defective retinoid transport and function in late onset Alzheimer's disease. Proc Natl Acad Sci USA 2003, 5:2901-2905.

11. Corcoran JP, So PL, Maden M: Disruption of the retinoid signalling pathway causes a deposition of amyloid beta in the adult rat brain. Eur $J$ Neurosci 2004, 4:896-902.

12. Goodman AB: Retinoid receptors, transporters, and metabolizers as therapeutic targets in late onset Alzheimer disease. J Cell Physiol 2006, 3:598-603.

13. Palha JA, Goodman AB: Thyroid hormones and retinoids: a possible link between genes and environment in schizophrenia. Brain Res Rev 2006, 1:61-71.

14. Husson $M$, Enderlin V, Delacourte A, Ghenimi $N$, Alfos S, Pallet V, Higueret P: Retinoic acid normalizes nuclear receptor mediated hypo-expression of proteins involved in beta-amyloid deposits in the cerebral cortex of vitamin A deprived rats. Neurobiol Dis 2006, 1:1-10.

15. Bremner JD, McCaffery P: The neurobiology of retinoic acid in affective disorders. Prog Neuropsychopharmacol Biol Psychiatry 2008, 2:315-331.

16. Etchamendy N, Enderlin V, Marighetto A, Vouimba RM, Pallet V, Jaffard R, Higueret P: Alleviation of a selective age-related relational memory deficit in mice by pharmacologically induced normalization of brain retinoid signaling. J Neurosci 2001, 16:6423-6429.

17. Mingaud F, Mormede C, Etchamendy N, Mons N, Niedergang B, Wietrzych M, Pallet V, Jaffard R, Krezel W, Higueret P, Marighetto A: Retinoid hyposignaling contributes to aging-related decline in hippocampal function in short-term/working memory organization and long-term declarative memory encoding in mice. J Neurosci 2008, 1:279-291.

18. Chiang MY, Misner D, Kempermann G, Schikorski T, Giguère V, Sucov HM, Gage FH, Stevens CF, Evans RM: An essential role for retinoid receptors RARbeta and RXRgamma in long-term potentiation and depression. Neuron 1998, 6:1353-1361.

19. Misner DL, Jacobs S, Shimizu Y, de Urquiza AM, Solomin L, Perlmann T, De Luca LM, Stevens CF, Evans RM: Vitamin A deprivation results in reversible loss of hippocampal long-term synaptic plasticity. Proc Natl Acad Sci USA 2001, 20:11714-11719.

20. Etchamendy N, Enderlin V, Marighetto A, Pallet V, Higueret P, Jaffard R: Vitamin A deficiency and relational memory deficit in adult mice: relationships with changes in brain retinoid signalling. Behav Brain Res 2003, 1-2:37-49.

21. Krezel W, Ghyselinck N, Samad TA, Dupé V, Kastner P, Borrelli E, Chambon P: Impaired locomotion and dopamine signaling in retinoid receptor mutant mice. Science 1998, 5352:863-867.

22. Gossen M, Bujard H: Tight control of gene expression in mammalian cells by tetracycline-responsive promoters. Proc Natl Acad Sci USA 1992, 12:5547-5551.

23. Furth PA, St Onge L, Böger $H$, Gruss $P$, Gossen M, Kistner A, Bujard H, Hennighausen $L$ : Temporal control of gene expression in transgenic mice by a tetracycline-responsive promoter. Proc Natl Acad Sci USA 1994, 20:9302-9306.

24. Mayford M, Bach ME, Huang YY, Wang L, Hawkins RD, Kandel ER: Control of memory formation through regulated expression of a CaMKII transgene. Science 1996, 5293:1678-1683.

25. Gu XL, Long CX, Sun L, Xie C, Lin X, Cai H: Astrocytic expression of Parkinson's disease-related A53T alpha-synuclein causes neurodegeneration in mice. Mol Brain 2010, 3:12.

26. Damm K, Heyman RA, Umesono K, Evans RM: Functional inhibition of retinoic acid response by dominant negative retinoic acid receptor mutants. Proc Natl Acad Sci USA 1993, 7:2989-2993.

27. Uchida S, Sakai S, Furuichi T, Hosoda H, Toyota K, Ishii T, Kitamoto A, Sekine M, Koike K, Masushige S, Murphy G, Silva AJ, Kida S: Tight regulation of transgene expression by tetracycline-dependent activator and repressor in brain. Genes Brain Behav 2006, 1:96-106.

28. Perlmann T, Rangarajan PN, Umesono K, Evans RM: Determinants for selective RAR and TR recognition of direct repeat HREs. Genes Dev 1993, 7B:1411-1422. 
29. Shimuta M, Yoshikawa M, Fukaya M, Watanabe M, Takeshima H, Manabe T: Postsynaptic modulation of AMPA receptor-mediated synaptic responses and LTP by the type 3 ryanodine receptor. Mol Cell Neurosci 2001 5:921-930.

30. Niisato K, Fujikawa A, Komai S, Shintani T, Watanabe E, Sakaguchi G, Katsuura G, Manabe T, Noda M: Age-dependent enhancement of hippocampal long-term potentiation and impairment of spatial learning through the Rho-associated kinase pathway in protein tyrosine phosphatase receptor type Z-deficient mice. J Neurosci 2005, 5:1081-1088.

31. Zucker RS, Regehr WG: Short-term synaptic plasticity. Annu Rev Physiol 2002, 64:355-405.

32. Fukushima $H$, Maeda R, Suzuki R, Suzuki A, Nomoto M, Toyoda H, Wu LJ, Xu H, Zhao MG, Ueda K, Kitamoto A, Mamiya N, Yoshida T, Homma S, Masushige S, Zhuo M, Kida S: Upregulation of calcium/calmodulindependent protein kinase IV improves memory formation and rescues memory loss with aging. J Neurosci 2008, 40:9910-9919.

33. Suzuki A, Fukushima H, Mukawa T, Toyoda $H$, Wu LJ, Zhao MG, Xu H, Shang Y, Endoh K, Iwamoto T, Mamiya N, Okano E, Hasegawa S, Mercaldo V, Zhang Y, Maeda R, Ohta M, Josselyn SA, Zhuo M, Kida S: Upregulation of CREB-mediated transcription enhances both short- and long-term memory. J Neurosci 2011, 24:8786-802.

34. Kogan JH, Frankland PW, Blendy JA, Coblentz J, Marowitz Z, Schütz G, Silva AJ: Spaced training induces normal long-term memory in CREB mutant mice. Curr Biol 1997, 1:1-11.

35. Squire $L R$, Alvarez $P$ : Retrograde amnesia and memory consolidation: a neurobiological perspective. Curr Opin Neurobiol 1995, 5:169-177.

36. Dudai $Y$ : Consolidation, fragility and the road to the engram. Neuron 1996, 17:367-370.

37. McGaugh JL: Memory-a century of consolidation. Science 2000, 287:248-251.

38. Abel T, Nguyen PV, Barad M, Deuel TA, Kandel ER, Bourtchouladze R: Genetic demonstration of a role for PKA in the late phase of LTP and in hippocampus-based long-term memory. Cell 1997, 5:615-626.

39. Kida S, Josselyn SA, Peña de Ortiz S, Kogan JH, Chevere I, Masushige S, Silva AJ: CREB required for the stability of new and reactivated fear memories. Nat Neurosci 2002, 4:348-355.

40. Suzuki A, Josselyn SA, Frankland PW, Masushige S, Silva AJ, Kida S: Memory reconsolidation and extinction have distinct temporal and biochemical signatures. J Neurosci 2004, 20:4787-4795.

41. Chen N, Napoli JL: All-trans-retinoic acid stimulates translation and induces spine formation in hippocampal neurons through a membraneassociated RARalpha. FASEB J 2008, 1:236-245.

42. Aoto J, Nam Cl, Poon MM, Ting P, Chen L: Synaptic signaling by all-trans retinoic acid in homeostatic synaptic plasticity. Neuron 2008, 2:308-320.

43. Maghsoodi B, Poon MM, Nam Cl, Aoto J, Ting P, Chen L: Retinoic acid regulates RARalpha-mediated control of translation in dendritic RNA granules during homeostatic synaptic plasticity. Proc Natl Acad Sci USA 2008, 41:16015-16020.

44. Poon MM, Chen L: Retinoic acid-gated sequence-specific translational control by RARalpha. Proc Natl Acad Sci USA 2008, 51:20303-20308.

45. Ding Y, Qiao A, Wang Z, Goodwin JS, Lee ES, Block ML, Allsbrook M, McDonald MP, Fan GH: Retinoic acid attenuates beta-amyloid deposition and rescues memory deficits in an Alzheimer's disease transgenic mouse model. J Neurosci 2008, 45:11622-11634.

46. Nagpal S, Saunders M, Kastner P, Durand B, Nakshatri H, Chambon P: Promoter context- and response element-dependent specificity of the transcriptional activation and modulating functions of retinoic acid receptors. Cell 1992, 6:1007-1019.

47. Hasegawa S, Furuichi T, Yoshida T, Endoh K, Kato K, Sado M, Maeda R, Kitamoto A, Miyao T, Suzuki R, Homma S, Masushige S, Kajii Y, Kida S: Transgenic up-regulation of alpha-CaMKII in forebrain leads to increased anxiety-like behaviors and aggression. Mol Brain 2009, 2:6.

48. Hosoda H, Motohashi J, Kato H, Masushige S, Kida S: A BMAL1 mutant with arginine 91 substituted with alanine acts as a dominant negative inhibitor. Gene 2004, 2:235-241.

49. Hosoda H, Kato K, Asano H, Ito M, Kato H, Iwamoto T, Suzuki A, Masushige S, Kida S: CBP/p300 is a cell type-specific modulator of CLOCK/BMAL1-mediated transcription. Mol Brain 2009, 2:34.

50. Thor DH, Wainwright KL, Holloway WR: Persistence of attention to a novel conspecific: some developmental variables in laboratory rats. Dev Psychobiol 1982, 1:1-8.
51. Kim R, Moki R, Kida S: Molecular mechanisms for the destabilization and restabilization of reactivated spatial memory in the Morris water maze. Mol Brain 2011, 4:9.

52. Suzuki A, Mukawa T, Tsukagoshi A, Frankland PW, Kida S: Activation of LVGCCs and CB1 receptors required for destabilization of reactivated contextual fear memories. Learn Mem 2008, 6:426-433.

53. Mamiya N, Fukushima H, Suzuki A, Matsuyama Z, Homma S, Frankland PW, Kida S: Brain region-specific gene expression activation required for reconsolidation and extinction of contextual fear memory. J Neurosci 2009, 2:402-413

54. Zhang $Y$, Fukushima $H$, Kida S: Induction and requirement of gene expression in the anterior cingulate cortex and medial prefrontal cortex for the consolidation of inhibitory avoidance memory. Mol Brain 2011, $4: 4$

55. Manabe T, Togashi H, Uchida N, Suzuki SC, Hayakawa Y, Yamamoto M, Yoda H, Miyakawa T, Takeichi M, Chisaka O: Loss of cadherin-11 adhesion receptor enhances plastic changes in hippocampal synapses and modifies behavioral responses. Mol Cell Neurosci 2000, 6:534-546.

doi:10.1186/1756-6606-5-8

Cite this article as: Nomoto et al:: Dysfunction of the RAR/RXR signaling pathway in the forebrain impairs hippocampal memory and synaptic plasticity. Molecular Brain 2012 5:8.

\section{Submit your next manuscript to BioMed Central and take full advantage of:}

- Convenient online submission

- Thorough peer review

- No space constraints or color figure charges

- Immediate publication on acceptance

- Inclusion in PubMed, CAS, Scopus and Google Scholar

- Research which is freely available for redistribution

Submit your manuscript at www.biomedcentral.com/submit
Ciomed Central 